\title{
PERFORMAN REPRODUKSI DAN PRODUKSI TERNAK BABI PADA USAHA PETERNAKAN RAKYAT DI DUA LOKASI BERBEDA
}

\author{
SURANJAYA, I G., M. DEWANTARI, I K. W. PARIMARTHA, \\ I W. SUKANATA, DAN I N. T. ARIANA \\ Fakultas Peternakan, Universitas Udayana \\ email : suranjaya_gede@yahoo.co.id
}

\begin{abstract}
ABSTRAK
Penelitian dilakukan dengan teknik survei terhadap peternak usaha peternakan babi rakyat di Desa Kebek dan Penginyahan, Payangan-Gianyar. Pengambilan sampel dilakukan secara "purposive random sampling" terhadap 20 orang peternak di setiap lokasi dan pendekatan eksploratif dilakukan untuk mendeskripsikan manajemen produksi dan reproduksi yang diterapkan. Data dianalisis secara deskriptif dan untuk mengkaji manajemen produksi dan reproduksi diantara kedua lokasi itu digunakan Uji T (Two Independent Sample T Test). Hasil penelitian menunjukkan rataan produktivitas babi induk di Kebek dan Penginyahan yaitu litter size: 9,50 $\pm 1,65$ vs $10,86 \pm 1,68$ ekor, jumlah melahirkan per tahun: $2,10 \pm 0,32$ vs $2,29 \pm 0,49$ kali, umur sapih anak : $29,00 \pm 2,11$ vs 29,00 $\pm 1,91$ hari, dan ketiga peubah itu masing-masing tidak berbeda nyata $(\mathrm{P}>0,05)$. Rataan jumlah anak disapih di Kebek dan Penginyahan masing-masing 7,90 $\pm 1,45$ vs 9,43 $\pm 1,99$ ekor $(\mathrm{P}<0,05)$, berat sapih anak : 7,20 $\pm 1,69$ vs $5,29 \pm 0,57 \mathrm{~kg}(\mathrm{P}<0,05)$. Masa kering dan umur afkir induk di Kebek nyata lebih tinggi dibanding di Penginyahan $(\mathrm{P}<0,05)$. Sementara pada manajemen penggemukan, umur awal untuk digemukkan dan lama pemeliharaan adalah tidak berbeda antara kedua lokasi ( $\mathrm{P}>0,05)$, sedangkan bobot awal dan bobot potong di Kebek nyata lebih tinggi dibanding dengan di Penginyahan yaitu masing-masing $14,00 \pm 1,15$ vs $12,20 \pm 1,79 \mathrm{~kg}$ dan $126,50 \pm 11,80$ vs $114 \pm 10,84 \mathrm{~kg}(\mathrm{P}<0,05)$.
\end{abstract}

Kata kunci: performans reproduksi, performan produksi, usaha peternakan rakyat

\section{REPRODUCTION AND PRODUCTION PERFORMANCE OF PIG ON LOCAL FARM AT TWO DIFFERENT LOCATIONS}

\begin{abstract}
The research was conducted in a survey of farmers on the pig farm business in the Kebek and Penginyahan village, Payangan-Gianyar. Purposive random sampling of 20 farmers in each location and explorative approach was conducted to describe the production and reproduction management applied. Data were analyzed descriptively and to study production and reproduction management between the two sites was Two Independent Sample T Test. The results showed the average productivity of pigs in Kebek and Penginyahan that is litter size: $9,50 \pm 1,65$ vs $10,86 \pm 1,68$ tail, annual litter size : 2,10 $\pm 0,32$ vs 2,29 $\pm 0,49$ times, weaning age: 29,00 $\pm 2,11$ vs $29,00 \pm 1,91$ day, and the three variables were not significantly different $(\mathrm{P}>0,05)$. The average number of piglet weaned in Kebek and Penginyahan was $7.90 \pm 1,45$ vs $9,43 \pm 1,99$ head, weaning weight of piglet $7,20 \pm 1,69$ vs $5,29 \pm 0.57 \mathrm{~kg}(\mathrm{P}<0.05)$. The dry period and the age of culled of sow in Kebek is significantly higher than in Penginyahan $(\mathrm{P}<0.05)$. Whereas in fattening management, early age to fatten and length of maintenance is not different between the two locations $(\mathrm{P}>0,05)$, whereas the live and slaughtering weight in Kebek are significantly higher than those in Penginyahan that is $14.00 \pm 1,15$ vs. $12.20 \pm 1,79 \mathrm{~kg}$ and $126,50 \pm 11,80$ vs. $114 \pm 10,84 \mathrm{~kg}(\mathrm{P}<0,05)$.
\end{abstract}

Keywords: reproduction performance, production performance, local pig farm

\section{PENDAHULUAN}

Usaha peternakan babi skala rakyat saat ini belum mampu menunjukkan produksi optimal sehingga tidak dapat mengimbangi permintaan daging yang terus meningkat. Rendahnya produktivitas ternak babi itu baik dari sisi reproduksi maupun produksinya masih menjadi kendala. Di lain pihak potensi ternak babi sebenarnya diandalkan sebagai penghasil daging karena persentase karkasnya mencapai $75 \%$ dari bobot hidup sehingga menjadikan babi sebagai ternak yang berpotensi dikembangkan sebagai penghasil daging 
(Sihombing, 1997). Peningkatan produktivitas ternak babi dapat dilakukan disamping melalui perbaikan mutu genetiknya juga dapat melalui peningkatan kualitas manajemen pemeliharaannya.

Ternak babi adalah ternak yang sangat potensial dikembangkan untuk memenuhi kebutuhan akan daging karena mempunyai kemampuan berkembangbiak yang cepat dan memiliki litter size yang tinggi (Parakkasi, 1990). Jumlah anak babi yang dilahirkan per induk (litter size) dan hidup akan menentukan banyaknya ternak sapihan yang akan diperoleh. Dalam upaya untuk menghasilkan litter size dan persentase anak hidup sampai disapih yang tinggi diperlukan manajemen produksi dan reproduksi yang baik. Menurut Ardana dan Putra (2008) manajemen reproduksi adalah semua bentuk usaha yang diterapkan untuk meningkatkan produktivitas usaha perbibitan, sedang manajemen produksi adalah segala upaya yang diberlakukan untuk memperbaiki performan ternak mulai fase starter, grower dan finisher.

Di Bali usaha pemeliharaan babi lebih banyak dilakukan sebagai usaha peternakan rakyat oleh masyarakat di perdesaan dengan jumlah pemilikan ternak yang terbatas. Produktivitas ternak babi pada usaha peternakan rakyat ini masih rendah yang disebabkan oleh kondisi manajemen reproduksi dan produksi di tingkat peternak tergolong sederhana. Manajemen budidaya (on farm) yang baik dan benar juga belum diadopsi oleh peternak dengan baik. Meskipun demikian, usaha peternakan babi di Bali sampai saat ini masih akan tetap bertahan dan terus berkembang. Hal ini disebabkan karena ternak babi memiliki peranan dan keterkaitan yang sangat erat dengan sisi kehidupan sosial dan budaya masyarakat.

Wilayah kecamatan Payangan Kabupaten Gianyar adalah sentra peternakan babi rakyat di Bali dengan jumlah usaha cukup banyak dan berkembang dengan baik. Terdapat dua lokasi usaha peternakan babi rakyat dengan jumlah peternak cukup banyak yaitu di Desa Kebek dan Desa Penginyahan. Usaha peternakan babi rakyat di kedua lokasi itu sudah berjalan dan berkembang cukup lama, namun sedikit informasi yang diketahui menyangkut performa reproduksi dan produksi dari ternak babi itu serta aspek teknis pemeliharaan yang diterapkan.

\section{MATERI DAN METODE}

\section{Pengambilan Sampel}

Pengambilan sampel dilakukan secara purposive random sampling, masing-masing sebanyak 20 orang peternak pada usaha peternakan babi rakyat di Desa Kebek dan Penginyahan, Kecamatan PayanganGianyar.

\section{Pengumpulan Data.}

Pengumpulan data dilakukan dengan teknik survei lapangan yaitu teknik pengumpulan data dengan menggunakan kuesioner/daftar pertanyaan dan wawancara/interview yaitu teknik untuk menggali informasi untuk kepentingan penelitian dengan melakukan tanya- jawab atau dialog antara peneliti dan responden.

Data yang dikumpulkan antara lain manajemen produksi meliputi: perkandangan, penyediaan pakan, kesehatan ternak, teknis pemeliharaan, teknis penggemukan, pemasaran dan manajemen reproduksi meliputi : pemilihan bibit, penangan induk dan pejantan, teknis perkawinan, pengafkiran ternak; Informasi data tambahan yang berkaitan diperoleh melalui observasi langsung di lapangan atau wawancara dengan mereka yang berperan pada usaha peternakan itu.

\section{Analisis Data}

Tabulasi dilakukan terhadap data primer dan sekunder selanjutnya dianalisis secara deskriptif. Untuk melihat perbedaan pelaksanaan managemen produksi dan reproduksi diantara dua lokasi usaha peternakan rakyat itu, maka data yang diperoleh dianalisis dengan Uji Beda Dua Rata-rata dilakukan dengan Uji T (Two Independent Sample T Test) menurut Steel dan Torrie (1980) dengan rumus:

$$
\begin{aligned}
& s_{g a b}^{2}=\frac{\left(n_{1}-1\right) s_{1}^{2}+\left(n_{2}-1\right) s_{2}^{2}}{n_{1}+n_{2}-2} \\
& t_{\mathbf{h i t}}=\frac{s_{\mathbf{t}}-x_{\mathbf{z}} \sqrt{\frac{1}{n_{1}}+\frac{1}{n_{\mathbf{z}}}}}{s_{\text {dimana, }}} \\
& \mathrm{t}_{\text {hit }}=\text { nilai thitung } \\
& \mathrm{s}^{2}=\text { ragam } \\
& \mathrm{s}_{\text {gab }}=\text { simpangan baku gabungan } \\
& \mathrm{n}_{1}=\text { jumlah sampel 1 } \\
& \mathrm{n}_{2}=\text { jumlah sampel 2 }
\end{aligned}
$$

Selanjutnya nilai t hitung dibandingkan dengan nilai t $\alpha$;db dan bila :

Nilai t hitung < $\mathrm{t} \alpha ; \mathrm{db}$, maka terima $\mathrm{H}_{\mathrm{o}}$ atau tolak $\mathrm{H}_{1}$ dan jika thitung > $\mathrm{t} \alpha$; db, maka tolak $\mathrm{H}_{\mathrm{o}}$ atau terima $\mathrm{H}_{1}$.

\section{HASIL DAN PEMBAHASAN}

Profil usaha peternakan babi yang dilakukan oleh responden di Kebek dan Penginyahan termasuk katagori usaha peternakan rakyat. Jenis usaha peternakan babi di Kebek terdiri dari 50\% usaha perbibitan dan 50\% usaha gabungan (perbibitan dan penggemukan), sedangkan di Penginyahan terdiri dari 50\% usaha perbibitan, 
$30 \%$ penggemukan dan 20\% gabungan. Jenis ternak babi yang dipelihara hampir 90\% adalah babi landrace dan sekitar 10\% adalah jenis babi yang lain termasuk babi bali. Status kepemilikan ternak di Kebek adalah 100\% milik sendiri dengan kisaran pemilikan ternak produktif antara $4-35$ ekor atau rata-rata $=13,10$ ekor per peternak, sedangkan di Penginyahan 100\% ternak milik sendiri dengan jumlah pemilikan ternak berkisar $3-46$ ekor atau rataan 19,50 ekor. Ardana dan Putra (2008) menyatakan bahwa manajemen reproduksi adalah semua bentuk usaha yang diterapkan untuk meningkatkan produktivitas usaha perbibitan, sedangkan manajemen produksi adalah segala upaya yang diberlakukan untuk memperbaiki performan ternak mulai fase starter, grower dan finisher. Menurut Sihombing (2006) bahwa parameter performan reproduksi pada ternak babi meliputi litter size, jumlah anak yang disapih, mortalitas anak, umur sapih, masa kering, sementara parameter performan produksi antara lain: berat lahir, berat sapih, laju pertumbuhan.

\section{Performan Reproduksi}

Performan reproduksi babi induk pada usaha peternakan rakyat dari masing-masing lokasi ditampilkan seperti pada Tabel 1.

\begin{tabular}{lccc}
\multicolumn{4}{c}{ Tabel 1. Performan reproduksi babi induk pada usaha perbibitan } \\
\hline \multicolumn{1}{c}{ Variabel } & Kebek & Penginyahan & Signifikansi \\
\hline Litter Size (ekor) & $9,50 \pm 1,65$ & $10,86 \pm 1,68$ & 0,12 \\
Umur anak disapih (hr) & $29,00 \pm 2,11$ & $29,00 \pm 1,91$ & 1,00 \\
Jumlah anak disapih (ekor) & $7,90 \pm 1,45$ & $9,43 \pm 1,99$ & 0,04 \\
Bobot sapih (kg) & $7,20 \pm 1,69$ & $5,29 \pm 0,57$ & 0.01 \\
Jumlah melahirkan/th & $2,10 \pm 0,32$ & $2,29 \pm 0,49$ & 0,35 \\
Masa kering induk (hr) & $7,30 \pm 0,95$ & $5,57 \pm 0,79$ & 0,00 \\
Umur afkir induk (th) & $6,00 \pm 0,67$ & $5,00 \pm 0,58$ & 0,00 \\
\hline
\end{tabular}

Sistem perkawinan babi induk di Kebek dan Penginyahan adalah tidak berbeda yaitu 100\% menggunakan kawin alam dan tidak ada menggunakan kawin buatan atau IB. Namun jumlah pejantan di kedua lokasi (desa) hanya mencapai 2-5 ekor. Hal ini disebabkan karena pemeliharaan pejantan membutuhkan biaya perawatan dan biaya pakan yang cukup tinggi. Pejantan aktif yang ada di masing-masing lokasi dipakai melayani sekitar 70 ekor babi induk. Penggunaan pejantan untuk mengawini betina pertama kali dilakukan pada kisaran umur $10-12$ bulan dan ratarata digunakan sebanyak 1 kali/hari dengan frekuensi penggunaan mencapai 1-2 kali per minggu. Lama waktu penggunaan pejantan sampai saat diafkir (umur afkir) berkisar antara $5-6$ tahun dengan rata-rata 5,33 $\pm 0,57$ tahun. Sebenarnya pejantan dapat dipakai mengawini betina pertama kali pada umur $7-8$ bulan. Menurut Siagian (1999) pejantan yang berumur di bawah 15 bulan hendaknya dipakai mengawini betina tidak lebih dari 25 kali per bulan, sedangkan pejantan dewasa dapat digunakan 20 - 40 kali per bulan dan ratio pejantan dengan betina dapat sampai $1: 50$. Menurut Sihombing (2006), seekor pejantan muda dapat kawin kandang dengan 8 - 10 ekor babi dara selama satu periode 4 minggu, sedangkan pejantan dewasa dapat mengawini $10-12$ ekor.

Litter size adalah jumlah anak yang lahir per induk per kelahiran. Litter size induk (LS) di Kebek dan Penginyahan secara rata-rata masing-masing 9,50 $\pm 1,65$ ekor dan 10,86 $\pm 1,68$ ekor $(\mathrm{P}>0,05)$. Secara umum seekor induk babi mempunyai litter size 8-12 ekor anak babi dengan lama kebuntingan 112-120 hari (Eusebio, 1980). Bangsa babi juga dapat mempengaruhi litter size misalnya bangsa babi Duroc litter sizenya 10,24 ekor sedangkan babi landrace 10,94 ekor (Milagres et al., 1983). Garndner et al. (1990) menyatakan induk yang mengalami cekaman selama kebuntingan dapat menurunkan litter sizenya sehingga perlu manajemen yang benar untuk menghindari cekaman pada induk terutama satu minggu sebelum beranak. Jumlah litter size adalah menggambarkan keunggulan induk dan pejantan disamping kualitas tatalaksana yang diberikan kepada ternak itu (Lasley, 1978).

Rataan umur sapih (US) anak di desa Kebek dan Penginyahan masing-masing 29,00 $\pm 2,11$ dan $29,00 \pm 1,91$ hari $(\mathrm{P}>0,05)$. Umur sapih adalah umur paling muda pada saat anak dapat dipisahkan dari induk tanpa pengurangan berat badan (Toelihere, 1977). Waktu sapih anak di Kebek dan Penginyahan tidak jauh berbeda yaitu berkisar 25 - 30 hari, ini menunjukkan bahwa responden peternak di kedua desa itu paling lambat setelah anak berumur 30 hari langsung dipisahkan dengan induknya. Hal ini dilakukan untuk memberi kesempatan kepada induk untuk dikawinkan kembali bila waktu birahinya sudah tiba. Sesudah 6 minggu dari saat melahirkan produksi susu induk mulai menurun sehingga apabila tidak dilakukan penyapihan lebih awal dikhawatirkan anak babi akan kekurangan susu, disamping itu pada umur 30 hari anak sudah mampu mengkonsumsi pakan dengan baik. Menurut Sihombing (1997) waktu menyapih anak terlalu lama dapat menyebabkan penurunan bobot badan induk, memperpanjang waktu untuk mengawinkan induk kembali sehingga jumlah anak dihasilkan per induk per tahun berkurang.

Rata-rata jumlah anak yang disapih ( $\mathrm{ADS}$ ) di Kebek yaitu 7,90 $\pm 1,45$ ekor nyata lebih rendah $(\mathrm{P}<0,05)$ dibandingkan dengan di Penginyahan yaitu 9,43 $\pm 1,99$ ekor. Hal ini disebabkan karena LS induk di Penginyahan memang lebih tinggi dari pada di Kebek meskipun secara statistika tidak signifikan. Secara umum $\sum$ ADS di kedua lokasi berkisar 6 - 12 ekor atau 
sekitar 75 - 81\% dari total LS induk sehingga besarnya mortalitas anak sampai saat disapih rata-rata mencapai 19 - 25\%. Mortalitas anak lebih banyak terjadi pada hari 1 - 3 dan hari ke-7 dari saat dilahirkan. Umur anak 3-10 hari termasuk masa kritis, pada saat itu anak babi sangat sensintif dan tidak berdaya menghadapi perubahan lingkungan yang berat. Disamping itu anak tidak mendapatkan kolostrum dari susu induk saat setelah dilahirkan sehingga kondisinya menjadi lemah dan mudah mengalami kematian. Kematian pada anak babi ini juga sering diakibatkan oleh kondisi cuaca dingin, lingkungan kandang yang kurang bersih dan terutama terserang mencret. Garndner et al. (1990) mendapatkan kematian anak yang lahir hidup sampai disapih mencapai 10\% yang diakibatkan tidak cukup mendapat kolostrum susu induk, sanitasi yang jelek, temperatur yang terlalu rendah, bobot lahir yang rendah, cekaman pada induk dan penyakit. Menurut Sihombing (1997) kematian anak babi saat menyusu bisa terjadi karena anak babi kekurangan oksigen, kelemahan dan tertindih atau terjepit oleh induk. Siagian (1985) menyatakan mortalitas anak babi pada periode starter dipengaruhi oleh produksi susu induk, jumlah litter size, keragaman berat lahir, manajemen induk, temparamen induk, anak lahir lemah atau cacat dan persentase mortalitas anak babi Duroc, Yorkshire dan Landrace pada minggu pertama adalah berturutturut sebesar $15,6 \%, 8,0 \%$ dan $8,5 \%$.

Kisaran bobot sapih (BS) anak di kedua lokasi Kebek dan Penginyahan adalah 5-10 kg dengan rataan masingmasing 7,20 $\pm 1,60 \mathrm{~kg}$ dan 5,29 $\pm 0,57 \mathrm{~kg}(\mathrm{P}<0,05)$. Berat sapih (BS) anak di Kebek nyata lebih tinggi dibanding dengan di Penginyahan. Hal ini mungkin disebabkan karena LS induk di Kebek lebih rendah sehingga ketersediaan susu induk untuk anak babi masih mencukupi. Pertumbuhan anak dari baru lahir sampai disapih tergantung dari ketersediaan dan produksi susu induknya. Kemampuan induk dalam menghasilkan air susu akan mempengaruhi pertumbuhan anak itu selanjutnya (Parakkasi (1990). Hal ini disebabkan karena jumlah litter zise dan kemampuan induk untuk memelihara (menyusui) anak-anaknya akan mempengaruhi waktu penyapihan dan pertumbuhan anak babi. Aritonang (1997) menyatakan bahwa secara umum pertambahan berat badan harian anak babi yang masih dalam asuhan induknya adalah rata-rata $147 \mathrm{~g}$ dengan kisaran 105 - $181 \mathrm{~g} /$ ekor/hari, dan tidak terdapat perbedaan pertambahan berat badan harian antara bangsa babi murni dan persilangan.

Masa kosong atau masa kering (MK) induk yaitu lama waktu jeda dari induk setelah anaknya disapih sampai birahi dan dikawinkan kembali. Rata-rata MK induk di Kebek dan Penginyahan masing-masing $7,30 \pm 0,95$ dan $5,57 \pm 0,79$ hari $(\mathrm{P}<0,05)$. Menurut
Ardana dan Putra (2008) MK induk babi idealnya selama 7 hari. Waktu MK dapat lebih lama atau lebih cepat adalah sangat tergantung dari kondisi induk dan kualitas pakan yang diberikan. Induk babi menyusui dengan pemeliharaan dan pemberian pakan yang kurang baik akan cepat menjadi kurus, apalagi jumlah anaknya cukup banyak. MK induk di Desa Kebek nyata lebih tinggi atau lebih lama $(\mathrm{P}<0,05)$ dari pada di Penginyahan. Hal ini disebabkan karena hampir 50\% induk babi di Kebek memiliki MK lebih dari 7 hari, sementara di Penginyahan MK induk rata-rata berkisar 5-7 hari.

Umur afkir (UA) induk yaitu lama waktu seekor induk dari saat mulai dipelihara sampai dia diafkir atau dikeluarkan dari peternakan. Umur afkir (UA) induk di Kebek dan Penginyahan secara rata-rata masing-masing 6,00 $\pm 0,67$ tahun dan $5,00 \pm 0,58$ tahun $(\mathrm{P}<0,05)$. UA induk di Kebek nyata lebih lama dari pada di Penginyahan. Berdasarkan UA itu secara umum seekor induk mampu menghasilkan anak atau beranak sebanyak 10 - 16 kali selama dia dipelihara di peternakan itu. Proses pengafkiran induk di suatu peternakan adalah lebih banyak berdasarkan atas faktor kesehatan, kesuburan dan sifat keibuan dari induk tersebut. Pengafkiran induk di Penginyahan lebih cepat adalah disebabkan oleh faktor kesehatan induk itu sendiri dan juga karena terlalu gemuk sehingga tingkat kesuburannya telah menurun. Induk afkir biasanya langsung dijual oleh peternak sebagai ternak potong.

\section{Performan Produksi}

Secara umum manajemen produksi pada usaha penggemukan di peternakan rakyat di Kebek dan Penginyahan sudah berlangsung cukup baik. Performan produksi usaha penggemukan berdasarkan atas bobot awal, capaian bobot potong, lama waktu pemeliharaan ditampilkan seperti pada Tabel 2.

\begin{tabular}{lccc}
\multicolumn{4}{l}{ Tabel 2. Performans produksi ternak babi } \\
\hline \multicolumn{1}{c}{ Variabel } & Kebek & Penginyahan & Signifikansi \\
\hline Umur awal digemukkan (hr) & $42,50 \pm 6,35$ & $45,00 \pm 5,00$ & 0,46 \\
Bobot awal (kg) & $14,00 \pm 1,15$ & $12,20 \pm 1,79$ & 0,03 \\
Bobot potong (kg) & $126,50 \pm 11,80$ & $114 \pm 10,84$ & 0,04 \\
Lama pemeliharaan (bln) & $4,4 \pm 0,46$ & $4,70 \pm 0,45$ & 0,25
\end{tabular}

Untuk di Kebek ternak mulai digemukkan pada kisaran umur 35 - 55 hari dengan rataan 42,5 $\pm 6,35$ hari, sedangkan di Penginyahan pada kisaran umur 40 -50 hari dengan rataan $45,00 \pm 5,00$ hari. Umur awal ternak mulai digemukkan pada usaha penggemukan di Kebek dan Penginyahan tidak berbeda nyata $(\mathrm{P}>0,05)$. Umur setelah 30 hari dianggap sebagai umur ideal ternak mulai digemukkan karena sedang berada pada masa pertumbuhan. 
Bobot awal ternak mulai digemukkan untuk Desa Kebek berkisar 12 - $15 \mathrm{~kg}$ dengan rataan $14 \pm 1,15 \mathrm{~kg}$, sedangkan untuk Desa Penginyahan berkisar $10-15 \mathrm{~kg}$ dengan rataan $12,20 \pm 1,79 \mathrm{~kg}$. Rataan bobot awal ternak mulai digemukkan di Kebek nyata lebih tinggi $(\mathrm{P}<0,05)$ dibandingkan dengan di Penginyahan. Kisaran bobot awal $10-15 \mathrm{~kg}$ adalah bobot ideal untuk mulai digemukkan karena pencapaian bobot potong diatas 100 kg dengan lama pemeliharaan $4-5$ bulan lebih mudah dicapai. Ternak babi landrace termasuk ternak yang menghasilkan litter size lebih banyak dengan interval generasi yang lebih singkat dibanding jenis ternak babi lainnya, sehingga dengan potensi reproduksi yang tinggi itu babi landrace sangat berpeluang dijadikan sebagai ternak potong komersial (Siagian, 1999).

Lama pemeliharaan yaitu waktu saat ternak mulai digemukkan sampai ternak itu dijual. Secara umum lama pemeliharaan yang ideal adalah 4 bulan, karena diatas 4 bulan keuntungan akan menurun dan sebaliknya biaya pakan akan menjadi lebih tinggi. Rataan lama pemeliharaan di Kebek dan Penginyahan masing-masing 4,4 $\pm 0,46$ dan 4,70 $\pm 0,45$ bulan $(\mathrm{P}>0,05)$ dengan capaian bobot potong untuk Kebek dan Penginyahan masing-masing $126,50 \pm 11,80$ dan $114 \pm 10,84 \mathrm{~kg}$. Capaian bobot potong di Kebek nyata lebih tinggi $(\mathrm{P}<0,05)$ dari pada di Penginyahan. Hal ini disebabkan karena bobot awal ternak mulai digemukan untuk Kebek nyata lebih tinggi dari pada Penginyahan. Pertumbuhan ternak setelah disapih memang sepenuhnya tergantung dari kemampuan individu itu sendiri (faktor genetik) disamping juga oleh faktor pakan yang diberikan. Produktivitas ternak babi sebagai ternak penghasil daging sangat diandalkan. Secara umum persentase karkas babi yaitu rata-rata $75 \%$ dari bobot hidup dan menjadikan babi sebagai ternak yang berpotensi sebagai sumber daging (Sihombing, 1997). Peningkatan produksi daging babi untuk pemenuhan kebutuhan daging bagi masyarakat dapat dilakukan melalui perbaikan genetik dan peningkatan kualitas lingkungan.

\section{SIMPULAN}

Dari hasil penelitian dapat disimpulkan bahwa manajemen reproduksi dan produksi pada usaha peternakan rakyat di kedua lokasi (desa) sudah baik dan memadai. Manajemen reproduksi induk di Desa Penginyahan adalah lebih baik yaitu jumlah anak disapih nyata lebih banyak, sementara manajemen produksi pada usaha penggemukan di Desa Kebek nyata lebih efisien yaitu capaian bobot potong nyata lebih tinggi dibanding dengan di Penginyahan pada satu masa periode produksi.

\section{UCAPAN TERIMA KASIH}

Ucapan terima kasih disampaikan kepada Bapak Rektor Universitas Udayana dan Dekan Fakultas Peternakan Universitas Udayana atas dukungan dana dan fasilitas yang diberikan untuk pelaksanaan penelitian ini serta kepada para peternak di Desa Kebek dan Desa Penginyahan atas kerjasamanya.

\section{DAFTAR PUSTAKA}

Ardana, I. B. K. dan D. K. H. Putra. 2008. Ternak Babi Manajemen Reproduksi, Produksi dan Penyakit. Udayana University Press. Denpasar.

Aritonang, D. 1997. Babi: Perencanaan dan Pengelolaan Usaha. Penerbit PT. Penebar Swadaya. Jakarta.

Eusebio, J. A. 1980. Pig Production in the Tropic. Intermediate Tropical Agriculture Series. University of the Philipines, Los Banos.

Garndner, J. A. A., A. C. Dunkin, dan L. C. Lloyd. 1990. Pig Production in Australia. Globe Press. Pig Research Council, Canberra, Australia.

Lasley, J. F. 1978. Genetics of Livestock Improvement. $3^{\text {rd }}$. Ed. Prentice-Hall of India Provate Limited New Delhi 110001.

Milagres, J. C., L. M. Fedalto, A. E. Silva, M, DE, and J. A. A. Peraira. 1983. Source of variation in litter size and weight birth and 21 days of age in Duroc, Landrace, Large White Pigs. Anim. Breed. Abstr.51 (7): 552.

Parakkasi, A. 1990. Ilmu Gizi dan Makanan Ternak Monogastrik. Angkasa, Bandung.

Siagian, P. H. 1985. Studi tentang performans dari bangsa ternak babi Landrace, Duroc dan Yorkshire. Institut Pertanian Bogor. Proyek Peningkatan/ Pengembangan Perguruan Tinggi, Bogor.

Siagian, P. H. 1999. Manajemen Ternak Babi. Jurusan Ilmu Produksi Ternak. Institut Pertanian Bogor.

Sihombing, D.T.H.1997. Ilmu Ternak Babi. Ed.-1. Gadjah Mada University Press. Bulaksumur, Yogyakarta.

Sihombing, D.T.H. 2006. Ilmu Ternak Babi. Ed. 2. Gadjah Mada University Press. Bulaksumur, Yogyakarta 55281.

Steel, G.D. and J.H. Torrie. 1980. Prinsip dan Prosedur Statistika (terjemahan). Pt. Gramedia Pustaka Utama. Jakarta.

Toelihere, M. R. 1977. Fisiologi Reproduksi pada Ternak. Angkasa, Bandung. 